\title{
A SET OF MONITORING METHODS AND METHODS IN THE TRAINING OF 12-14 YEAR OLD VOLLEYBALL PLAYERS
}

\section{Jumanov O.S.}

Ph.D., Associate Professor, Scientific And Methodological Provision Of Physical Education And Sports Specialists Under The Ministry Of Physical Training And Sports Of The Republic Of Uzbekistan

\section{ABSTRACT}

This article describes the effective use of pedagogical tests to assess the level of physical and technicaltactical training of volleyball players aged 12-14.

KEYWORDS: - Intensity, volleyball players, technical tactical trainings, control, methods, jumping

\section{INTRODUCTION}

Nowadays, new, more modern exercise methods are constantly being sought in order to achieve a high level of sportsmanship in sports. This is determined by the fact that the modern level of success in the sport is very high.

Given the characteristics of age and changes in the exercise process, the weight of exercise performance has increased significantly in recent years due to an increase in its intensity. Having studied the tools and methods of primary sports training, it should be noted that speed and strength exercises should be in the forefront in the process of playing volleyball. Over the years, we have conducted experimental work aimed at identifying effective tools and control methods used in the early stages of training young athletes.

The experiment was conducted in 2019-2020 with young volleyball players aged 12-13, who train at the Children and Youth Sports School in Tashkent.

Based on the results of the experiment, we offer some methodological recommendations on how to conduct training, select and use individual exercises.

1. Active development of speed and power qualities should begin at the age of 9-10. The focus of training in this direction will lead to a better mastery of volleyball techniques, a significant improvement in the quality of jumping, which is necessary for volleyball players. 
CURRENT RESEARCH JOURNAL OF PEDAGOGICS 2(8): 84-86, August

2021 DOI: https://doi.org/10.37547/pedagogics-crjp-02-08-19

ISSN 2767-3278

(C)2021 Master Journals

\section{Crossref do) 81 Google}

Accepted 26 $6^{\text {th }}$ August, 2021 \& Published 31 ${ }^{\text {th }}$ August, 2021

2. Special tools for training young volleyball players in terms of speed and strength are selected based on the characteristics of the exercise being studied, which gives the best effect for the exercise. These tools should be selected based on the structure and nature of the neuromuscular tension that occurs during the performance of basic exercises and taking into account the development of basic qualities at this stage of mastering sports techniques. Training sessions are held three times a week for two hours. The high level of movement in the training allows you to achieve high results in speed and strength training at the end of the second year of training, significantly increasing the functional capacity of the young athlete's body.

3. During training, it is necessary to replace exercise with lighter exercise, taking into account the effect of weight on the body. Muscle relaxation exercises are required to help quickly restore the energy energy expended after highintensity exercise. Performing exercises aimed at developing speed, strength, endurance and skill together, alternately, is the most optimal way to comprehensively improve all the necessary qualities.

4. Athletes of this age are required to use exercises in the form of games and circles, and the loads are short-lived, in order to conduct training in a lively and emotional way.

5. The amount of repetition of exercises should not exceed four to five times and should be stopped after the rate of performance has decreased, rest is given until the body has fully recovered. In the development of speed endurance, the interval method is used, and the exercises are performed several times at a maximum (high) level of speed and $85-95 \%$ of the force expended.

6. According to the content of the training, it consists mainly of running and jumping exercises to develop speed and strength. Exercises performed with weights (up to $30 \%$ of their own weight) can also be used in training.

7. Elements of movement games, sports games, gymnastics and acrobatics should also be widely used.

8. General and special training should be tested to control the level of physical fitness. Based on the results of each stage, it is possible to assess the effectiveness of the learning process, make certain adjustments to the training plans.

They are conducted simultaneously with medical examinations at the beginning of the preparation period, at the end of it and at the end of the main stage.

The following tests can be used as pedagogical tests to assess the level of physical and technicaltactical readiness:

- running for $30 \mathrm{~m}$ (sec);

- Running like a mok $6 \times 5$ m. (sec);

- long jump from a standing position (sm);

- vertical jump (sm);

- throwing a stuffed ball from behind the head with both hands (weight $1 \mathrm{~kg}$ );

The choice of these control exercises is not random. $30 \mathrm{~m}$. running gives an idea of the speed qualities of a young athlete; $6 \times 5 \mathrm{~m}$. mokide running characterizes speed endurance; long jump, high jump, throwing a stuffed ball - shows the qualities of speed and power.

When controlling the level of technical readiness, it is necessary to set the time to pass the ball to each other, two passes of the ball from above and below, and so on.

The application of high levels of physical activity to young volleyball players, of course, necessitates the study of the body's ability to withstand these loads and work. For this reason, the PWC170, MPK test is recommended to determine performance. 
CURRENT RESEARCH JOURNAL OF PEDAGOGICS 2(8): 84-86, August

2021 DOI: https://doi.org/10.37547/pedagogics-crjp-02-08-19

ISSN 2767-3278

(C)2021 Master Journals

Crossref do: 81 Google

Accepted $26^{\text {th }}$ August, 2021 \& Published 31 th August, 2021

It is possible to effectively manage the coordination of the training process and the training of young volleyball players by using control tools and methods to determine the level of physical qualities and work ability of athletes.

\section{RefERENCES}

1. Волков Л.П. Теория и методика детского и юношеского спорта.

2. -Киев, Олимпийская литература, 2002. 294 c.

3. Айрапетьянц Л.Р. Волейбол. //Учебник для высших учебных заведений.-Т.: Zarqalam. 2006. - 240 c.

4. Беляев А.В. Обучение технике игры в волейбол и её совершенствование. //Методическое пособие. -М.: Олимпия, 2008. - 54 c.

5. Гарипов А.Т., Клещев Ю.Ю., Фомин Е.В. Скоростно-силовая подготовка юных волейболисток. //Методические рекомендации. ВФВ, -М.: 2009. - 45 с.

Железняк Ю.Д., Чачин А.В., Сыромятников Ю.П. Волейбол. //Примерные программы для ДЮСШ и СДЮШОР. -М.: Советский спорт, 2009.$130 \mathrm{c.}$

6. Abdullaeva B.P. Abdullaeva F.T. Organization Of Swimming Lessons In

Preschool Institutions The american journal of social science and education

innovations. JULY 2020[ TAJSSEI]322ISSN
(e):2689-100X DOI:

https://doi.org/10.37547/tajssei/Volume0

2Issue 07-42

7. Abdullaeva B.P. Corruption in the field of education: assessments and ways to address. "Тенденции и перспективи развития науки и образования в условиях

глобализации".Международной научнопрактической интернет-конференции. г.Переяслав, Украина.2020 год 30

8. Abdullaeva B.P. Babaraximova B.P. Pardaev B.P.Using information and communication technologies in teaching process of various primary European Journal of Research and Reflection in Educational Sciences, 8 (10), 67-70. Progressive Academic Publishing, UKwww.idpublications.org 14.10.2020.

9. Abdullaeva B.P. Abdullaev F.T. Organization Of Swimming Lessons In Preschool Institutions THE AMERICAN JOURNAL OF SOCIAL SCIENCE AND EDUCATION INNOVATIONS. JULY 2020[ TAJSSEI]322ISSN (e):2689-100X DOI: https://doi.org/10.37547/tajssei/Volume0 2Issue 07-423.

10. Abdullayeva, B.P., \& Babaraximova, B. P. (2020). MAKTABGACHA TA'LIM MUASSASASIDA FUTBOL DARSLARINI TASHKIL ETISH METODIKASI. Academic Research in Educational Sciences http://ares.uz/jurnallar-sahifasi/ares-vol1-no-3-2020. 